【原著】

\title{
好みの単色彩光による感情刺激効果
}

一心理的および生化学的指標の評価から一

\section{Effectiveness of Preferable Color Light on Psychosomatic State Evaluated by Emotional Parameters and Biochemical Parameters}

齋藤ゆみ ${ }^{1, *}$, 羅 越 ${ }^{2}$, 笹山 哲 ${ }^{1}$, 齋藤邦明 ${ }^{1}$, 豊川博己 ${ }^{3}$ Yumi SAITO ${ }^{1, *}$, Etsu RA ${ }^{2}$, Satoshi SASAYAMA ${ }^{1}$, Kuniaki SAITO ${ }^{1}$, Hiroki TOYOKAWA ${ }^{3}$

1 京都大学大学院医学研究科人間健康科学系専攻

2 京都大学医学部人間健康科学科

3 京都大学大学院情報学研究科数理工学専攻

【要 旨】

目的：単色の色彩光による感情状態への刺激 効果を明らかにすること.

方法：スクリーンに投射の好みの単色彩光を 介入因子とし，その心理的刺激効果を多面的 感情状態および喠液中のストレスホルモン指 標を用いて測定した. 被験者は 20 名. 実験 群には好みの単色彩光を, コントロール群に はそれ以外の色彩を 20 分間提示し, 各指標 を被験者内効果の比較で評価した.

結果：実験群では色彩刺激後に「非活動的快」 が有意に上昇し $(p=0.025)$ ，「抑うつ」や「倦 总感」が有意に低下した $(p=0.005, p=0.041)$. $\mathrm{CgA}$ の平均值は $4.54 \mathrm{pmol} / \mathrm{ml}$ から一旦上昇 し, 再び $4.96 \mathrm{pmol} / \mathrm{ml}$ と減少に転じた. コン トロール群では逆に上昇し, 両群の CgA 值 の変化パターンには有意差が認められた. ( $\mathrm{P}$ $<0.001)$

結論：好む色彩光は気分を沈め, 倦㤐感やう つ状態を緩和して，感情状態をポジティブな 方向に変化させることが示唆された.

【キーワード】

色彩光, 状態·特性不安検査, 多面的感情状 態尺度，唾液中のクロモグラニン，分泌型免 疫グロブリンA
1. はじめに

著者らはこれまで，個人の経験や心象，風土や文化な どによって影響を受け，その個人に打ける意味を包含す るであろら自然の造形をモチーフにしたオリジナルな色 彩映像によって，感情状態の自己統制をねらった簡易的 なストレスセルフケア媒体の開発を目的とした研究を行 い，何篇かの論文を報告してきた ${ }^{1-3)}$. 第 2 段階の基礎研 究では，個人のその時の気分や嗜好に合わせて固有な映 像を選択できるシステムを併用して，その個人に特異的 な色彩映像による心理的刺激効果を感情状態の指標，お よび生化学的指標を用いて評価した ${ }^{3)}$. その研究におけ る多面的感情状態指標 (MMS) の評価結果では, ポジティ ブな感情状態の内,「非活動的快 (Well being)」，「親和 (Friendliness)」の平均得点が色彩映像を見た後で有意に 上昇し $(\mathrm{P}<0.05)$ ，一方，ネガティブな感情状態の「抑ら つ・不安 (Depression)」,「倦总 (Boredom)」,「敵意 (Hostility) の平均得点がそれぞれ有意に低下した $(\mathrm{P}<0.05)$. 一方, 生化学的指標で，交感神経および副腎髄質系のクローム 親和性細胞から分泌される糖蛋白質であり4)，最近では 精神的ストレスの生化学的指標の一つとして多くの報告 があるクロモグラニン $\mathrm{A}(\mathrm{CgA})^{4-7)}$ の平均值は映像を見

受理日：2010 年 3 月 29 日

* 干606-8507 京都市左京区聖護院川原町 53 京都大学医学研究科人間健康科学 Tel: 075-751-3920 Fax: 075-751-3920 E-mail: ymsaito@hs.med.kyoto-u.ac.jp 
た後で有意な低下が認められ $(\mathrm{P}<0.01$ Bonferroni), 好ま しいと感じる色彩映像を見ることはストレス，あるいは 心の緊張状態を緩和すると考えられた。

本研究はこの結果を踏まえ, 色彩刺激の応用版として, 臨床現場において非常に体力の低下している患者さんに 対しても適応可能な, 視覚から入る刺激が少ない, 好み の単色彩光を用いてその心理的刺激効果を明らかにする ために研究を行った.

\section{2. 材料 · 方法}

\section{1 研究の概要}

本研究はコンピュータ上に好みの単色彩光をプロジェ クターを用いてスクリーンに投射し，やわらかい色彩の 空間を創りだし，これを介入因子として，その心理的刺 激としての効果をストレス・感情状態の評価指標执よび 生化学的ストレス指標を用いて明らかにしようとする実 験研究である。図 1 に実験手順の概観を示した。

\section{2 被験者}

本学の大学生及び大学院生に対して研究の目的, 方法, 個人情報の保護などに関する説明文章を配布し, 研究の 被験者を募り, 文書にて同意が得られた学生・職員を被 験者対象とした。個人情報の保護については，被験者は 名前とは別に記号化された対照表を作成して，別に保管 した. データ処理時，成果公表時のいずれの時点におい ても個人の特定可能性は無いことを説明した．被験者数 は，学部大学生及び大学院修士生の計 20 名（男性 6 名, 女性 14 名, 平均年齢 $25 \pm 5.5$ 歳) である.

\section{3 実施時期}

平成 21 年 6 月 25 日から 9 月 10 日までの期間で, 唾液 のストレス関連因子の分泌が安定すると報告されている

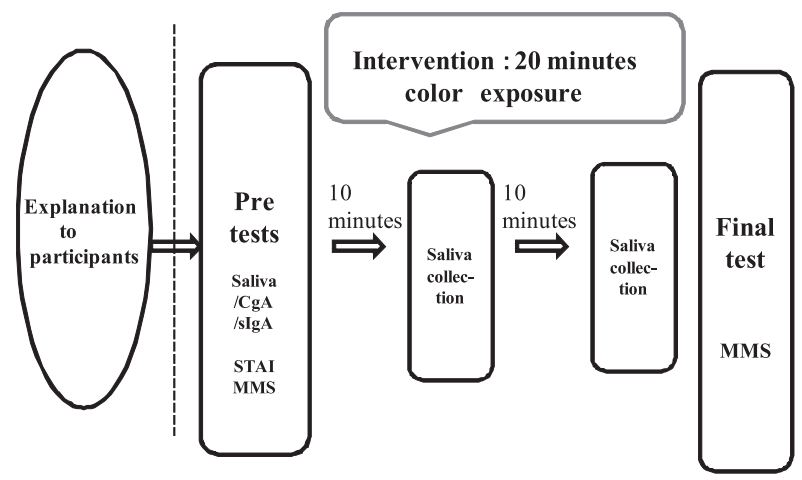

図 1 実験手順の概観

$\mathrm{CgA}$ ：クロモグラニン $\mathrm{A}, \operatorname{sIg} \mathrm{A}$ ：唾液中の免疫グロブリン $\mathrm{A}$
13 時から 17 時までの時間帯に実施した. 尚, 本研究は 被験者内比較で実施し, 各被験者とも3 日から 7 日の間 隔を開けて実験群とコントロール群の両群の被験者を経 験した．被験者の実験群，あるいはコントロール群の割 付はそれぞれ被験者同数になるよらにして，任意に選択 した。

\section{4 色彩の実験の方法と色彩の提示方法}

実験前のアンケート調査と唾液の採取は映像提示室 $\left(20 \mathrm{~m}^{2}\right)$ と同室内で実施し, 色彩提示は一名ずつ行い, 実 験時間内に実験室には被験者一人とした。

実験開始前に好夕の色を調査した。実験群に関しては 赤色, 青色, 黄色, 緑色, 桃色の 5 色彩のらちから最子 好久の色を, コントロール群には最も好きな色以外の残 りの 4 色の中からコンピュータによって任意に選択した ものを提示した。コントロール群の被験者には事前に何 色が提示されるかわからないことを説明した．実験途中 の唾液採取の指示等はスクリーンの右下に文字で現れる ようにした。

色彩の提示は広さ $20 \mathrm{~m}^{2}$ の一室の約半分の領域（約 $10 \mathrm{~m}^{2}$ ) を利用した。室温は摂氏 27 度に設定し, 実験中 は教室外からの光を遮断するよら扉や空等を黒い布で 覆った. その上に被験者の視線が対面する一面をシーツ （白色でしわのない織り目のつまった綿製の布） 3 枚で覆 い, スクリーンとした。実験中は部屋の照明は消し, 中 央にソファを一つ，その前にテーブルを設置し，テーブ ル上にはプロジェクター，コンピュータ，検体収集のた めのスピッツ類を置いた.

提示する色彩はコンピュータ上に設定されている 5 色 彩（RGB 赤色 : 255,0,0, 青色 : 0,0,255, 黄色 : 255,255,0, 緑色: 0,255,128, 桃色: 214,17,219）の単色彩をプロジェ クター（DATA PROJECTOR U4-232h，明るさ：1800ルー メン）を用いて実験室の被験者が対面する壁面に縦横約 $180 \times 150 \mathrm{~cm}$ で投影した。部屋の中は提示され多色彩以 外は無彩色のもののみにした. 実験室の様子を図 2 に示 した。

\section{5 収集するデータ項目}

ストレス状態を評価するための調査票である STAI (State-Trait Anxiety Inventory-Form : 状態-特性不安検査 日本語版, 資料 1) と多面的感情状態尺度 (Multiple Mood Scale; MMS 短縮版，資料 2）を用いて被験者のストレス および，感情状態を評価した ${ }^{8-10)}$ 。 また，ストレスの生 化学的指標として有効と考えられている唾液中のクロモ グラニン $\mathrm{A}(\mathrm{CgA})$, 扎よび分泌型免疫グロブリン $\mathrm{A}(\mathrm{s} \operatorname{IgA})$ を測定した ${ }^{11,12)}$. 


\subsection{1 ストレス及び多面的感情状態の評価}

STAI は不安を喚起する事象に対し, 自律神経の興奮な ぞを伴ら一過性の状況を 20 項目の状態不安尺度を用い て，それぞれ「全く違う」，「いくらか」，「まあそらだ」， 「その通りだ」の 4 段階の点数で評価し，また，日頃の不 安体験に対する比較的安定した反応傾向を 20 項目の特 性不安尺度を用いて，それぞれ「汪とんどない」，「とき たま」,「しばしば」,「しょっちゅう」の 4 段階の点数を 合計して評価する質問用紙である。本研究では「がん」 などの慢性的な疾患に伴う持続的ストレスやうつ状態に

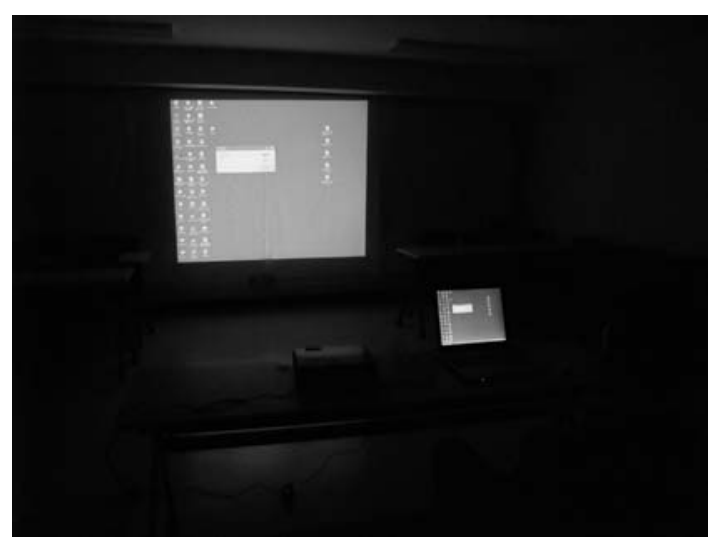

図 2 色彩実験の様子 色彩提示前の実験室の状沉を示す。
対して，色彩を用いてその感情状態の改善を図ることを 目的として扬り，アンケート結果から，STAI のマニュア ル基準に基づいて, 被験者を特性不安の高い群（40 点以 上），低い群（39 点以下）に分けて下記に示す各種指標 の結果を比較検討した.

多面的感情状態尺度 (Multiple Mood Scale; MMS 短縮 版）を用いて被験者の感情状態を評価した。この尺度は 「抑らつ・不安」,「敵意」,「倦急」,「活動的快」,「非活動 的快」，「親和」，「集中」，「驚愕」の 8 因子に分類された 40 の項目から構成されている. 各項目に対してそれぞれ 1 4 点の 4 段階の評点を割り当て各因子の合計点を算 出して感情状態を評価する。本研究では特に精神的スト レスに関連する感情状態因子に注目してその変化を検討 するために，ポジティブな感情状態である「活動的快」, 「非活動的快」，「親和」，拉よびネガティブな感情状態で ある「抑らつ」，「倦急」，「敵意」の計 6 因子の平均值の 変化を対象に統計学的検討を行った.

\section{5 .2 ストレスの生化学的指標の評価}

唾液中にカテコラミンと相関して内分泌され, 交感神 経活動の指標とされるクロモグラニン $\mathrm{A}(\mathrm{CgA})$, 分泌型 免疫グロブリン $\mathrm{A}(\mathrm{IgA})$ を色彩を見る前の 5 分以内, 色 彩を提示後 10 分, 色彩を提示後 20 分の 3 時点で測定した.

$\mathrm{CgA}$ は全身の神経内分泌組織に様々な濃度で存在し， 特に副腎髄質は最も分泌濃度が高いとされ，アドレナリ

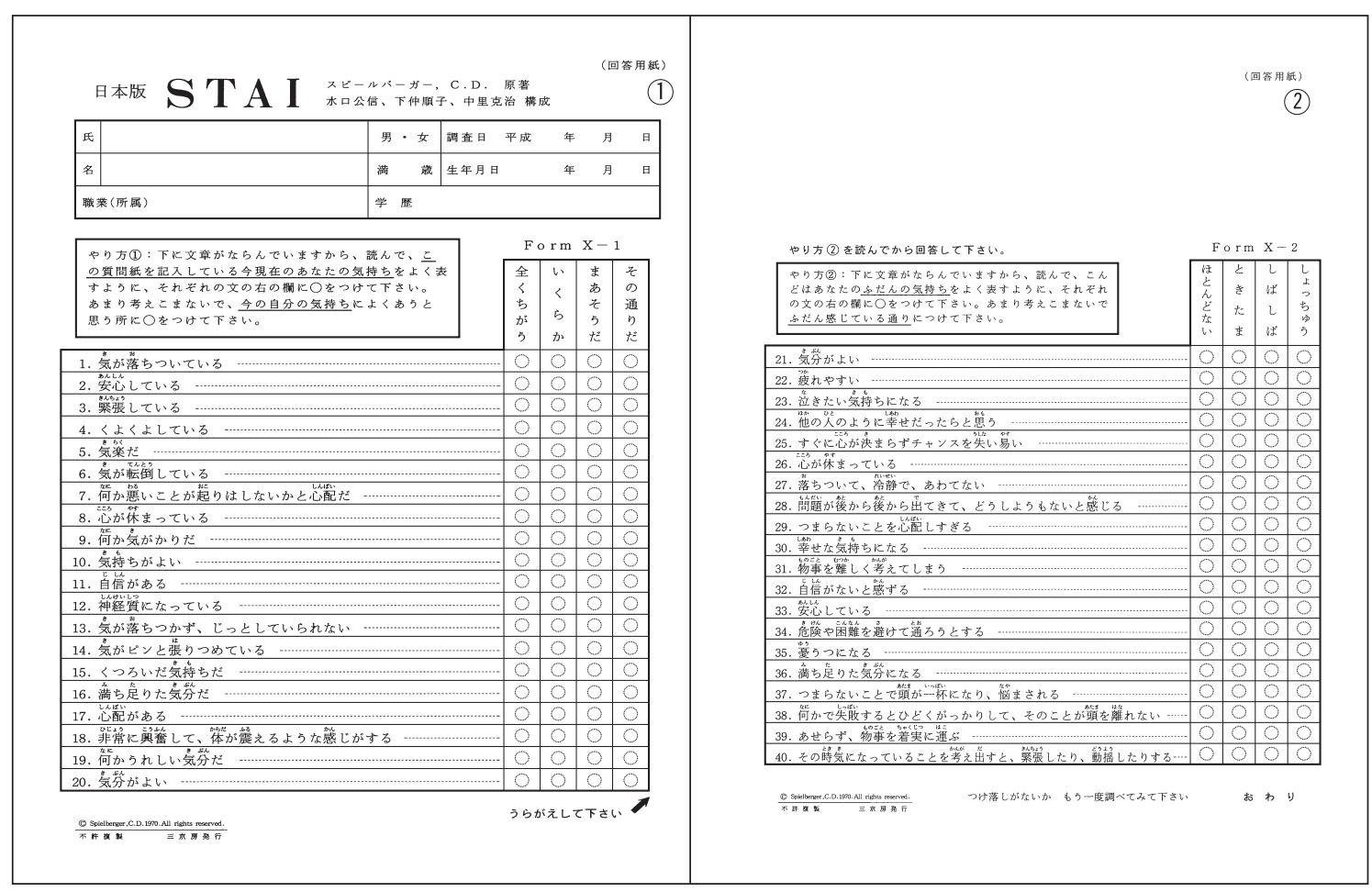




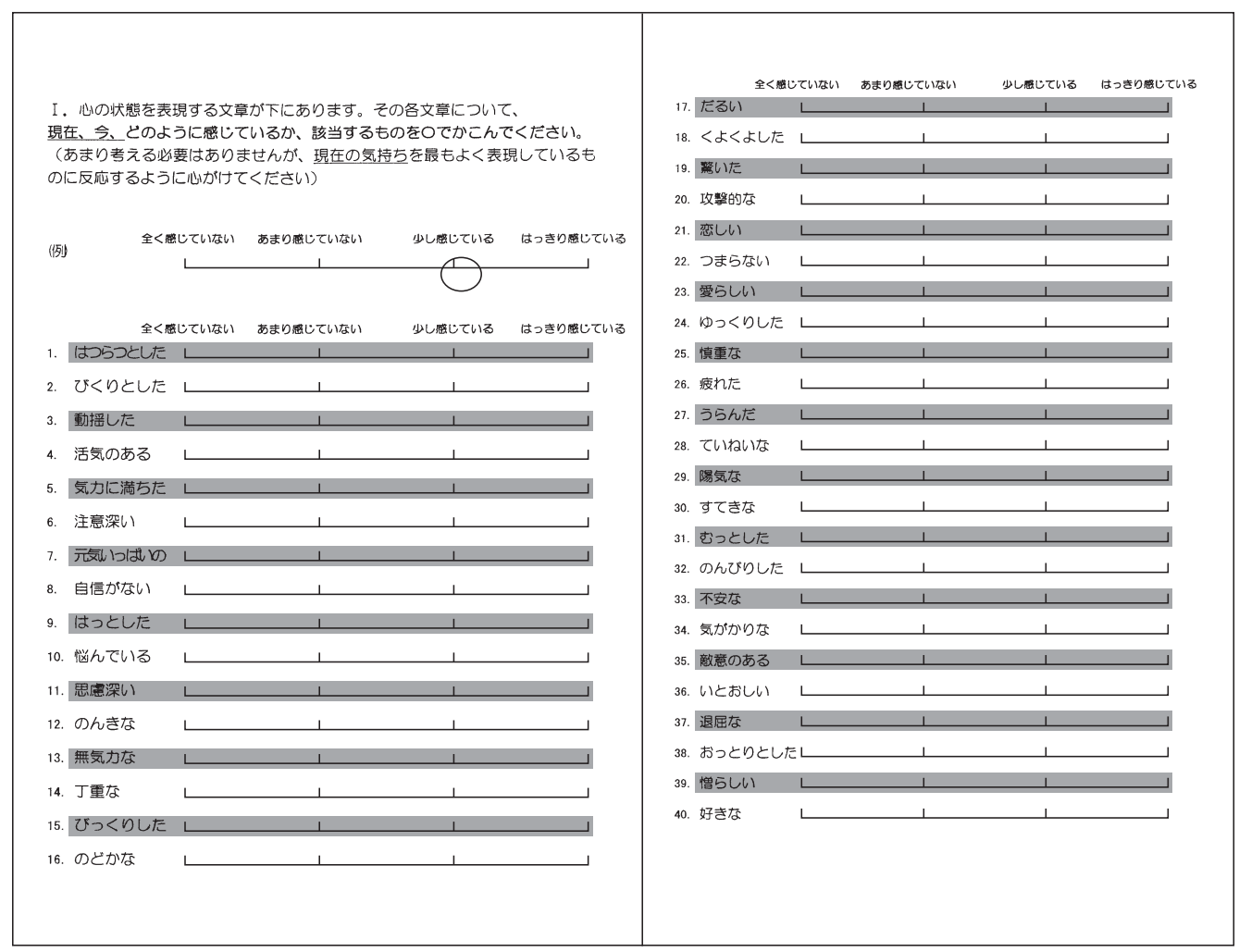

資料 2 多面的感情状態評価票

ンなどのカテコラミンに伴って交感神経および副腎髄質 系のクローム親和性細胞から分泌される糖蛋白質であ る4). 最近では精神的ストレスの生化学的指標の一つと して多くの研究が報告されている ${ }^{5-7)}$. 本研究ではこれら の 2 種の神経内分泌物質をストレスの生化学的指標とし て用いた.

唾液の採取には唾液採取用チューブのサリベット (Sarsted, Germany) を使用した。綿球に採取された検体は 検査を実施するまでの間， -20 度で保存した。各ストレ ス指標の検出にはヒトクロモグラニン A ELISA Kit（矢 内原), 分泌型免疫グロブリン A は EIA s-IgA (MBL CO., LTD) を使用し測定した。

\section{6 統計解析}

統計解析としてはウイルコクソン符号付順位和検定, 被験者内効果の検定，二元配置の分散分析 (ANOVA) 等 を実施した。

統計解析用のソフトウェアとしては，エクセル統計 Statcel Version 2, Windows，および，SPSS 16.oJ，を用い た. ANOVA は一般線形モデルの反復測定を用いて実行 した。それぞれの検定の有意水準は 5\%とした。

\section{3. 結 果}

\subsection{STAI による被験者の特性}

STAI による被験者の特性不安の結果を表 1 に示した. 本研究は被験者内比較であるため, 被験者は 3 7 日の間 隔をおいて実験群，コントロール群を経験した．被験者の 特性不安評価は実験群の時もコントロール群の時におい ても差はなく，非常に安定していた．STAI 得点 40 点以 上は 13 人 $(56 \%)$ であり, 本研究の被験者は標準より特 性不安の高い学生が多い傾向にあることが示唆された。

\section{2 単色彩の感情状態評価の結果}

好夕の色彩を提示した（被験者 $\mathrm{N}=20$ ）前後の多面的 感情状態の変化を図 3 に示した. 被験者は好む色彩に 20 分間曝された結果，ポジティブな感情である「非活動的 快 (Well being)」の気分が有意に上昇 $(\mathrm{p}=0.025)$ 乙, 逆に ネガティブな気分である「抑らつ・不安 (Depression)」状 態や「倦急感 (Boredom)」が有意に低下した $(\mathrm{p}=0.005, \mathrm{p}$ $=0.041)$. 被験者集団を特性不安の高低で分析してみる と, この結果は特性不安が高い被験者グループに適応し

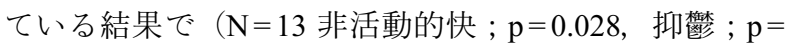
0.030 , 倦㤐 ; $p=0.01)$, 特性不安が低いグループ $(\mathrm{N}=7)$ 
表 1 状態・特性不安検査 (STAI) による被験者の特性不安值評 価の結果

\begin{tabular}{lrcccc}
\hline & $\mathrm{n}$ & score & mean & range & SD \\
\hline Experimental group & 13 & High & 48.6 & $42.6-61$ & 6.2 \\
& 7 & Low & 33.2 & $25-39$ & 4.8 \\
\hline Control group & 13 & High & 48.9 & $40-60$ & 5.7 \\
& 7 & Low & 33.7 & $27-38$ & 3.7 \\
\hline
\end{tabular}

STAI ; 状態 - 特性不安検査, SD ; 標準偏差

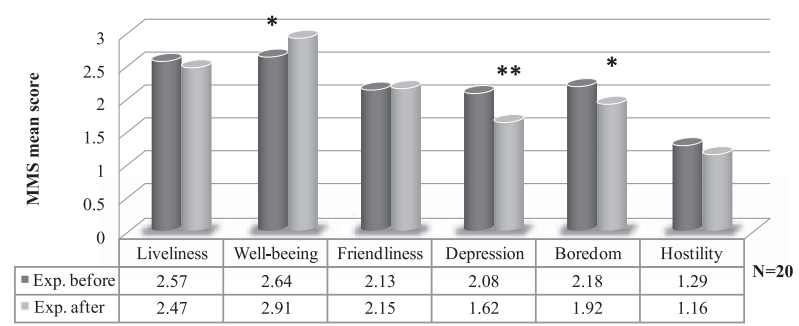

図 3 好又の色彩による多面的感情状態の変化 $*: \mathrm{p}<0.05, * *: \mathrm{p}<0.01$

では被験者数の少ないこともあるが，すべての因子で有 意差は認められなかった（結果非提示）。

実験群・コントロール群に抢ける色彩提示前後の感情 状態の変化を比較した結果を図 4-1 と示した.

ポジティブな感情状態を示す因子のうち，「活動的快 (Liveliness)」の MMS の平均得点は実験群では好久の色 彩を提示後で 0.1 低下したのに対して，好みではない色 彩を提示したコントロール群では 0.46 低下し, 両者に有 意な差が認められた $(p=0.019)$.「非活動的快 (Well being)」はそれぞれ実験群は 0.27 , コントロール群は 0.11 と上昇したが両者に有意な差は認められなかった。「親和 (Friendliness)」では実験群で 0.02 とわずかに上昇したの に対してコントロール群では 0.15 低下した.

ネガティブな感情状態を示す因子のうち，「抑うつ・不 安(Depression)」はそれぞれ実験群 0.46 , コントロール群 0.24 ，と低下したが，両者に有意な差は認められなかっ た。しかし，「倦急 (Boredom)」では実験群で 0.26 低下し たのに対して，コントロール群では逆に 0.12 上昇し，両 者に有意な差が認められた。「敵意 (Hostility)」は両群で わずかに低下したものの，両者に有意な差は認められな かった。

特性不安の高い被験者グループ(A) と低い被験者グ ループ (B) に分けて，それぞれのグループの被験者が好 みの色彩を提示された場合と，それ以外の色彩を提示さ れた場合の感情状態の変化について更に分析した結果を 図 4-2 に示した。特性不安が高いグループでは好みの色 彩提示に対して，活動的快の感情変化はほとんどないの

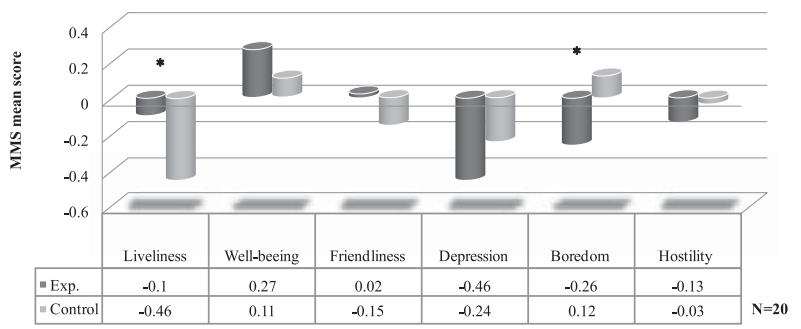

図 4-1 好又の色彩とそれ以外の色彩による多面的感情状態の 変化

*: p<0.05, Experi : 実験グループ ; Control: コントロールグループ
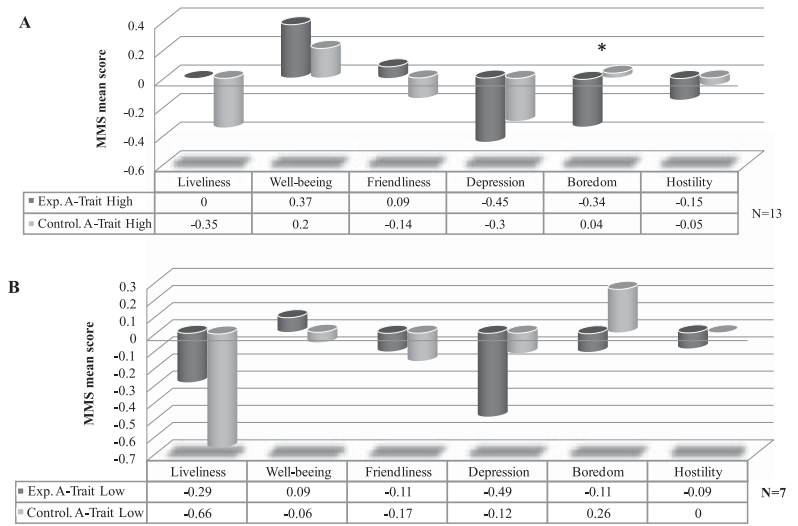

図 4-2 特性不安の高い被験者間 (A), 抢よび低い被験者間 (B) に打ける好みの色彩とそれ以外の色彩による多面的感情 状態の変化

A-Trait High：高特性不安群; A-Trait Low：低特性不安群 $*: \mathrm{p}=0.046$

に対して，好みでない色彩を提示した後は 0.35 低下し た。一方，非活動的快に関してはいずれの色彩提示に打 いても感情状態は上昇傾向を示した，倦怠感は好みの色 彩提示によって 0.34 減少したにもかかわらず，好み以外 の色彩では反って増加し，両者に有意な差がみられた $(\mathrm{p}$ $=0.046$ ). 同様に, 特性不安の低いグループ (B) では活動 的快は好及の色彩提示に比べて好及の色彩以外の色彩提 示では一段と低下した。 また，抑らつ状態は好久の色彩 提示によってょり大きく低下し，倦㤐感は好夕以外の色 彩では反って増加する傾向が示された，しかし，いずれ の因子も実験群，コントロール群で有意な差は認められ なかった。

尚，これまでの実験で被験者に好みと評価された色彩 は，桃色，黄色，緑，青がそれぞれ 23.5\%の被験者に選 択されたのに対して，赤は5\%であった。

\section{3 単色彩の生化学指標の評価結果}

色彩刺激前後の 3 時点に打忊る経時的 $\mathrm{CgA}$ 值の変化 を図 5-1 に示した. 
実験群では $\mathrm{CgA}$ 值の平均は実験前に $4.54 \mathrm{pmol} / \mathrm{ml}$ で あったものが色彩刺激によって $5.41 \mathrm{pmol} / \mathrm{ml}$ に一旦上昇 するものの, 20 分後には $4.96 \mathrm{pmol} / \mathrm{ml}$ と減少に転じてい る. これに対して, コントロール群では $3.47 \mathrm{pmol} / \mathrm{ml}$ から 色彩刺激の後に $4.1 \mathrm{pmol} / \mathrm{ml}$, 更に 20 後にも $5.23 \mathrm{pmol} / \mathrm{ml}$ と上昇し, この両群に打ける $\mathrm{CgA}$ 值の経時的変化のパ ターンには有意差が認められた（ $\mathrm{P}<0.001$, 多変量検定, 一般線型モデル). 尚, 実験群, コントロール群における 実験前の $\mathrm{CgA}$ 值に関しては両群に有意な差は久られな かった（ウイルコクスン符号つき順位和検定 $\mathrm{p}=0.3$ ).

図 5-2 は図 5-1 の $\mathrm{CgA}$ 值の経時的変化に対して, 被験 者を特性不安の高低のグループに分けてその変化の度合 いを比較した．特性不安の高いグループ (A) では好みの 色彩の提示に対して色彩刺激の影響は汪とんど見られ ず, $\mathrm{CgA}$ 值は $5.09 \mathrm{pmol} / \mathrm{ml}, 5.43 \mathrm{pmol} / \mathrm{ml}, 5.47 \mathrm{pmol} / \mathrm{ml}$ と わずかに上昇しているのに対して，好み以外の色彩提示 を受けたコントロール群では色彩刺激後に $\mathrm{CgA}$ 值は $3.46 \mathrm{pmol} / \mathrm{ml}, 4.03 \mathrm{pmol} / \mathrm{ml}, 5.19 \mathrm{pmol} / \mathrm{ml}$ と上昇し続けた。 両者の経時的変化パターンに有意差が認められた（多変 量検定，一般線型モデル $\mathrm{p}=0.015$ ).

一方, 特性不安の低いグループ (B) では好みの色彩提 示に対して $\operatorname{CgA}$ 值は $3.51 \mathrm{pmol} / \mathrm{ml}$ から色彩刺激後に $5.35 \mathrm{pmol} / \mathrm{ml}$ と上昇し, その後, $4.01 \mathrm{pmol} / \mathrm{ml}$ に減少した. しかし, 好久の色彩以外の色彩提示に打いては色彩刺激 後に $\mathrm{CgA}$ 值は $3.47 \mathrm{pmol} / \mathrm{ml}, 4.23 \mathrm{pmol} / \mathrm{ml}, 5.31 \mathrm{pmol} / \mathrm{ml}$ と 上昇し続け，両者の経時的变化パターンに有意さが認め られた $(\mathrm{p}=0.025)$.

色彩刺激前後の 3 時点における経時的 $\operatorname{sgA}$ 值の経時 的変化を図 6-1 に示した。 $\operatorname{sIgA}$ の平均值は好又の色彩を 提示した実験群では実験前に $134.02 \mu \mathrm{g} / \mathrm{ml}$ で, 色彩刺激 によって一旦 $190.27 \mu \mathrm{g} / \mathrm{ml}$ に上昇するものの, 10 分後に は $187.01 \mu \mathrm{g} / \mathrm{ml}$ とわずかに減少に転じているのに対し て，コントロール群では $121.25 \mu \mathrm{g} / \mathrm{ml}$ から, 色彩刺激の 後に $157.51 \mu \mathrm{g} / \mathrm{ml}$ に, 10 分後には $193.01 \mu \mathrm{g} / \mathrm{ml}$ に上昇し ている. この両群に打影 $\operatorname{sgA}$ 值の経時的変化のパター ンの差は有意であることが確認された（多変量検定，一 般線型モデル $\mathrm{P}<0.049)$. 尚, 実験群, コントロール群に おける実験前の $\operatorname{IgA}$ 值に関しては両群に有意な差はみら れなかった（ウイルコクスン符号つき順位和検定 $\mathrm{p}=$ $0.19)$.

図 6-2 は図 6-1 で示した SIgA 值の経時的変化に対して 被験者を特性不安の高低のグループに分けてその変化の 度合いを比較した. 特性不安の高いグループ $(\mathrm{A}, \mathrm{N}=13)$ で は好久の色彩刺激の結果， $\operatorname{sIgA}$ 值の分泌は $160.81 \mu \mathrm{g} / \mathrm{ml}$, $198.81 \mu \mathrm{g} / \mathrm{ml}$ と増加し, 20 分後に打いて子 $221.06 \mu \mathrm{g} / \mathrm{ml}$ と微上昇を示したのにたいして，好久以外の色彩提示に

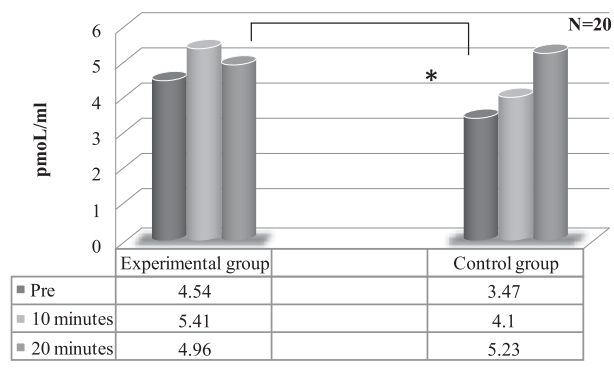

図 5-1 好みの色彩とそれ以外の色彩によるクロモグラニン A $(\mathrm{CgA})$ 值の変化

*: $\mathrm{p}<0.001$; Pre : 色彩提示前 ; 10 minutes : 色彩提示後 10 分 ; 20 minutes : 色彩提示後 20 分

$\mathbf{A}$

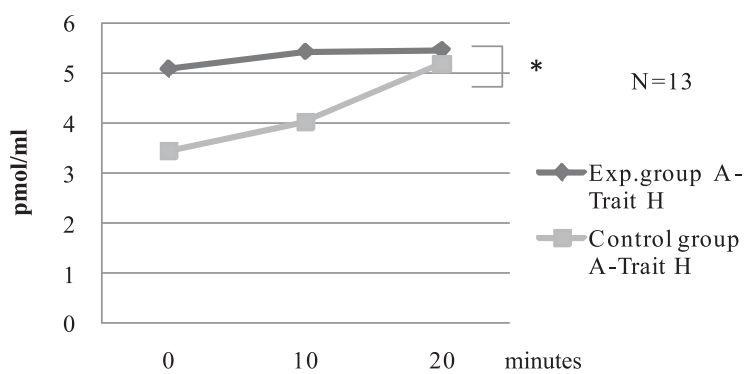

B

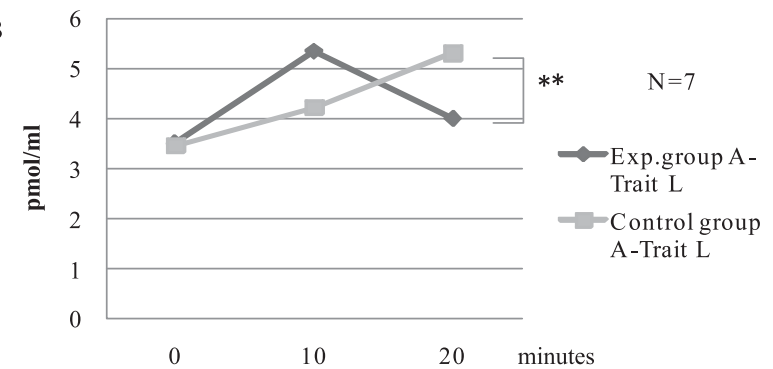

図 5-2 特性不安の高い被験者間 (A)，扣よび低い被験者間 (B) に打ける好みの色彩とそれ以外の色彩による唾液中のク ロモグラニン $\mathrm{A}(\mathrm{CgA})$ 值の変化

$*: \mathrm{p}<0.015 ; * *: \mathrm{p}<0.025$

A-Trait H : 高特性不安群; A-Trait L : 低特性不安群

おいては $130.45 \mu \mathrm{g} / \mathrm{ml}, 155.41 \mu \mathrm{g} / \mathrm{ml}, 195.46 \mu \mathrm{g} / \mathrm{ml}$ と上昇 乙続けた。 しかし，両者の経時的変化パターンに有意さ は認められなかった. 一方, 特性不安の低いグループ (B, $\mathrm{N}=7)$ では好及の色彩刺激によって一旦, $84.24 \mu \mathrm{g} / \mathrm{ml}$ から $174.40 \mu \mathrm{g} / \mathrm{ml}$ に上昇するものの, 20 分後には $123.75 \mu \mathrm{g} / \mathrm{ml}$ に低下した. 好久以外の色彩提示に打いては $104.15 \mu \mathrm{g} / \mathrm{ml}$, $161.4 \mu \mathrm{g} / \mathrm{ml}, 188.42 \mu \mathrm{g} / \mathrm{ml}$ と上昇し続けた。 しかし, 両者 の経時的変化パターンに有意さは認められなかった $(\mathrm{p}=$ $0.062)$. 


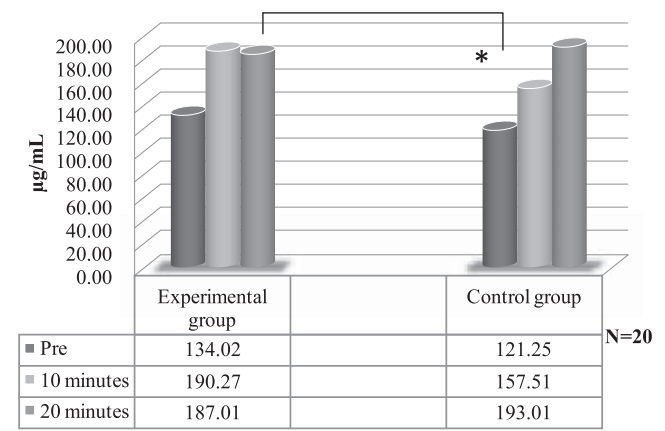

図 6-1 好みの色彩とそれ以外の色彩による唾液中の免疫グロ ブリン A (IgA) 值の変化

*: $\mathrm{p}<0.049$; Pre : 色彩提示前 ; 10 minutes : 色彩提示後 10 分 ; 20 minutes : 色彩提示後 20 分
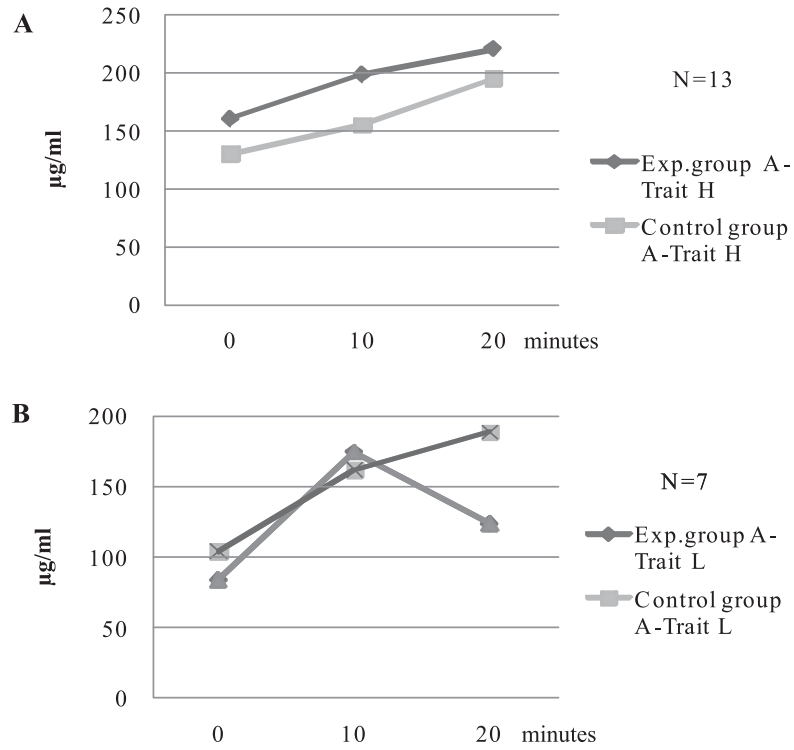

図 6-2 特性不安の高い被験者間 (A), および低い被験者間 (B) に打ける好みの色彩とそれ以外の色彩による免疫グロブ リン $\mathrm{A}(\mathrm{Ig} \mathrm{A})$ 值の変化

A-Trait H : 高特性不安群; A-Trait L : 低特性不安群

\section{4. 考 察}

著者らはこれまでオリジナルな色彩映像を用いたスト レス緩和媒体の研究開発を行ってきた、本研究は, より 視覚刺激が少ない単色彩の刺激であっても人の感情状態 やストレス状態に何らかの影響を与えることができるど らかを検証するため, 好又の色彩とそれ以外の色彩刺激 に扣ける感情状態や生化学的ストレス指標に対する影響 を調べた。

本研究は将来的に骨髄移植患者など易感染宿主やがん 等の慢性疾患によって持続的らつ状態やストレス状態に ある患者の重い感情を瘉やすことを目的としているため
色彩刺激としては直接的な強いひかり刺激ではなく，プ ロジェクターによってスクリーンに映し出し，なるべく その場の空間をその色彩でみたすことを考えた。

今回の研究結果は，単色彩に打いても好ましいと感じ ている色彩とそれ以外の色彩では人の感情状態 (図 4)や 生化学的ストレスホルモン指標（図 5,6）に対する反応 は異なっていることが示唆された. 感情状態の指標から は好ましいと感ずる色彩であれば気分を和らげ（非活動 的快の上昇), 倦吝感やうつ状態を緩和するなどの感情状 態の変化を誘発することが示唆された。 これは特性不安 の高い被験者により強く示された傾向であった. しかし， 自律神経系のホルモンであり精神的ストレス状態の指標 とされている $\mathrm{CgA}$ 值は特性不安が高い群では好みの色 彩に扣いても臣とんど変化がみられず，一方，特性不安 の低い被験者は, 7 人と人数的に評価の限界があるが, 好 みの色彩によって CgA の動態から緊張緩和がはかられ ていることが示唆された．このことは，特性不安の低い 被験者は何らかの刺激によって一時的に容易に緊張状態 を緩和できるのに対して，特性不安の高い被験者は持続 的・慢性的緊張状態であり，特性としての自律神経系の 緊張状態は一過性の刺激では容易に変化しないことを示 唆している可能性があるといえるか子知れない.しかし, この点に関しては，更に研究をすすめ，色彩刺激の情動 伝達系や自律神経系を介した内分泌の刺激伝達系につい て検討を深める必要があると考える.

また，好ましいと感ずる色彩や色彩映像によってもた らされた一時的な気分や感情の変化を長期的な変化とす るためには，あるいは，特性不安を変える変化をもたら すためには, 著者らのめざすストレス緩和媒体が日常的, 継続的に使用可能なセルフケア媒体として完成される必 要があることをあらためて認識した.

粘膜免疫応答の結果として増加する唾液 $\operatorname{sIgA}$ 值は精 神的なストレスに相関するとされ ${ }^{11)}$ ，また，慢性的なス トレス下では，産生が抑制され，急な心理的ストレスで は産生が上昇するといら報告がある ${ }^{12,13)}$ そとこで，今回 はストレスあるいは免疫の指標としての $\operatorname{sgA} の$ 測定も 行った. 色彩刺激に対する $\operatorname{sgA} の$ 動態は実験群，コント ロール群で, $\mathrm{CgA}$ 值とほとんど変わらない経時的変化パ ターンを示した. 本実験ではコントロール群で $\operatorname{sg} A$ 值が 増加したが，この結果は特性不安の高低両グループの分 析でも同様であった。つまり， $\operatorname{sgA}$ 值の経時的変動パ ターンの結果からも, 好又でない色彩刺激は生体にとっ て急な心理的ストレスとして捉えられ，精神的緊張が増 強したといえるかもしれない。ちなみに好みの色彩以外 の色彩に暴露されたコントロール群の被験者の中には実 験の途中で不快を感じたと述べる者もいた. 
唾液中の $\operatorname{IgA}$ に関しては様々なストレス因子や免疫刺 激によって変化すること，末た，個人差が大きく，検出 上の困難も存在することが知られて扣り ${ }^{14)}$, 検査結果の 分析に関しては, $\mathrm{CgA}$ と並んでストレス緩和媒体の有用 性評価の客観的指標として用いることができるようさら に研究を推進し, 今後の研究課題としたい.

\section{結 論}

1. 好久の色彩による軟らかい光刺激は一時的に感情を 静め，らつ状態や倦㤐感などのネガティブな感情を抑制 し, ストレスや緊張状態を緩和する傾向が示唆された。 特に特性不安の低い被験者では生化学的指標に扔いてこ の傾向は顕著であった.

2. 好夕以外の色彩による光刺激では活気が低下し，倦 怠感が増強し，ストレスや緊張状態が増強した。この傾 向は特性不安の高い被験者, 低い被験者にも共通していた。

\section{謝 辞}

本研究は 20 年度科学研究費補助（基盤研究 B）を受 け,「色彩映像の心理的効果一映像選択システムの有效性 の検証 (第 E508 号)」として, 京都大学「医の倫理委員 会」より承認を受けて行われた研究の一部である.

\section{助成源}

21 年度文部科学省研究助成

\section{参 考 文 献}

1）齋藤ゆ久，菅佐和子，多田春江ら。カラー映像によるス卜 レス緩和効果の研究. 京都大学医学部保健学科紀要. 2006; 2: $1-7$.

2) Saito $Y$, Tada H. Effects of color images on stress reduction: Using images as mood stimulants. JJNS 2007; 4: 1-8.

3）齋藤ゆ久，笹山 哲，菅佐和子ら。色彩映像の心理効果一 映像選択システムの併用に上る色彩映像の感情刺激効果の 検討一. 日本補完代替医療学会誌. 2008; 5: 225-232.

4) Winkler H, Fischer-Colbrie R. The chromogranins A and B: The first 25 years and future perspectives. Neuroscience 1992; 49: $497-528$.

5) Nakane H, Asami O, Yamada Y, et al. Salivary chromogranin A as an index of psychosomatic stress response. Biomedical Research 1998; 19: 401-406.

6) Obara S, Iwama H. Assessment of psychological tension after premedication by measurement of salivary chromogranin A. Journal of clinical anesthesia 2005; 17: 554-557.

7) Toda M, Morimoto K, Nagasawa S, et al. Change in salivary physiological stress markers by spa bathing. Biomedical research 2006; 27: 11-14.

8) 中里克治, 水口公信. 新しい不安尺度 STAI 日本語版の作 成. 心身医学. 1982; 22: 107-178.

9) 寺崎正治. 多面的感情尺度の作成と性格研究への応用. 磯 博行，岡 幸三編，情動・学習・脳. 二瓶社. 2002: 139-150

10) 寺崎正治, 岸本陽一, 古賀愛人. 多面的感情尺度の作成. 心理研究. 1992; 62: 350-356.

11) Kugler J. Mood and salivary immunoglobulin A. A review. Psychotherapy, Psychosomatic Medicine and Psychology 1991; 41: 232-242.

12) Mestecky J. Saliva as a manifestation of a common mucosal immunity system. Ann NY Acad Sci 1993; 694: 184-194.

13) Hucklebridge F, Lambert $S$, Clow A, et al. Modulation of secretory immunoglobulin $\mathrm{A}$ in saliva: response to manipulation of mood. Biol Psychol 2000; 53: 25-35.

14) Brandtzaeg P. Do salivary antibodies reliably reflect both mucosal and systemic immunity? Ann NY Acad Sci 2007; 1098: $288-311$. 


\author{
ABSTRACT \\ Effectiveness of Preferable Color Light on Psychosomatic State Evaluated by Emotional \\ Parameters and Biochemical Parameters \\ Yumi SAITO $^{1}$, Etsu RA ${ }^{2}$, Satoshi SASAYAMA ${ }^{1}$, Kuniaki SAITO ${ }^{1}$, Hiroki TOYOKAWA ${ }^{3}$ \\ ${ }^{1}$ Human Health Science, Graduate School of Medicine, Kyoto University \\ ${ }^{2}$ School of Human Health Sciences, Faculty of Medicine, Kyoto University \\ ${ }^{3}$ Department of Applied Mathematics and Physics, Graduate School of Informatics, Kyoto University
}

Objective: To assess the effectiveness of preferred colored light on psychosomatic state.

Methods: Preferred color light and other colored light were projected on a screen and shown to experimental and control subjects. To determine the effect of such light, mood adjective scores as determined by the Multiple Mood Scale (MMS) were measured as an emotional parameter, and levels of salivary chromogranin A $(\mathrm{CgA})$ and salivary immune globulin A were measured as biochemical parameters. This study was performed in a randomized, crossover design. These data were analyzed statistically and a $p$ value less than 0.05 was considered significant.

Results: After being exposed to preferred colored lights, mean MMS scores indicating positive moods, such as well-being increased significantly $(\mathrm{p}=0.025)$, and scores indicating negative moods, such as depression and boredom decreased significantly ( $p=0.005$, $\mathrm{p}=0.041$ ). Mean value of salivary $\mathrm{CgA}$ also decreased and was significantly different between experimental and control group ( $\mathrm{p}$ $<0.001)$.

Conclusion: Preferred colored light may be effective in promoting a calm positive state.

Key words: Colored light, State-trait anxiety inventory (STAI), Multiple mood scale (MMS), Salivary chromogranin A (CgA), Salivary immune globulin A (IgA) 